\title{
SCHOOL BASED FACTORS AFFECTING GIRLS ACADEMIC PERFORMANCE (KCSE) IN MIXED SECONDARY SCHOOLS: A CASE OF NAKURU MUNICIPALITY
}

\author{
Owuor Dorothy Akinyi \\ Chemisto Esther Musani \\ Kenyatta University-Department Of Education Administration And \\ Curriculum Development- Kenya
}

\begin{abstract}
This study intended to investigate School based factors affecting girls' performance in mixed secondary schools. The objectives of the study were to determine school - based factors, which affect girls' academic performance (KCSE) in mixed secondary, to suggest the possible strategies to counter the school based factors which affect girls' academic performance. The study sampled mixed Secondary Schools which are twelve in number using simple random technique to select six schools. From the sampled schools, an equal numbers of students were selected from form four classes in each school totaling 160 . Sixty (60) teachers were included in the study and six (6) head teachers .Data was collected using questionnaires for students and teachers. Interviews were for head teachers. The research employed a mixed method design technique. Data was analyzed using descriptive statistics i.e. frequencies, percentages, mean and Standard deviation. Scientific Package for Social Sciences (SPSS) was also used. The findings of the study were to provide to the education stakeholders to come up with strategies for countering the school based factors affecting girl's academic performance in KCSE in Nakuru Municipality. From the research findings, it was established that school based factors affecting girls' performance were KCPE intake, time wastage, and boy/ girl relationship. The recommendations made were, there should be more guidance and counselling in schools, increase bursaries, inviting resource persons to talk to girls, special relationship between girls and female teachers and separation of girl's classes from boys.
\end{abstract}

Keywords: School based factors, aces, and girls 


\section{Introduction}

Education is regarded as a powerful level for development in Kenya. It has often been referred to and described as the key to progress and social mobility (MoEST, 1999) Lack of the same on the other hand is considered to be the single most obstructive bottleneck to socio-economic betterment. In view of the above then it is not surprising that a large portion of the national budget in the country and indeed in most developing countries goes towards education (KNBS, 2006). Education plays a crucial role in preparing the young for their future roles in society. Education has become one of the basic rights which every citizen must have access to, therefore the need for education of both boys and girls should be stressed ( World Bank,2002)

The last decades of the twentieth century saw many concerted efforts in research into gender issues all over the world. In Africa, international bodies and educationalists began in the 1960's to look into the ways girls and women were fairing in education. Their findings were depressing. By 1970's pro female initiatives by some African governments to encourage enrolment of girls in schools was started. Consequently, low enrolment figures indicated in the earlier years (1960 -70) were in the 1990's shown to have improved. Kenyan females constituted nearly $50 \%$ of the children enrolled in grade one Forum for Africa Women Educationist (FAWE 1996). What about performance? Researchers and teachers have to recognize prejudicial practices which may still disadvantage girls particularly within classrooms, even where policy and statistics suggest that equality has been achieved.

Our education system in Kenya is characterized by examinations and therefore it is an issue that attracts public attention. These examinations are used as yardsticks for learning and selection purposes. Each parent is eager that his child passes the examination as it is the basic requirement for entrance into formal sector. It is a criteria for determining those who should proceed and pursue in the examination at each level. Therefore every student going through this system of formal education has to sit for these examinations in our case, Kenya Certificate of Secondary Education (KCSE). Every year whenever K.C.S.E results are released, single sex schools usually dominate the top positions. In 2004 KCSE, results summary at the top were single sex schools. Among the 50 (Fifty) top Schools, there were only four mixed schools three of which were private and only one public. The public school was Sacho High School; the private schools were Moi High School Kabarak, Nyahururu Elite School and Chemelil Sugar Academy. In the top ten girls schools only and boys had equal slots of five (5) each. This has led to the question, how come girls on their own perform better?(KNEC,2004). 
In $2005 \mathrm{KCSE}$, results the story was almost the same. Among the top 100 (one hundred) schools, there were only 10 mixed schools, 34 girls schools and 56 boys schools. The public mixed schools were Ober Secondary school which only had 28 students registering a mean of 9.3214; St. Georges mixed secondary school (8.1379) with 85 students and Uasin Gishu high school (KNEC,2005)

The rest seven were private mixed schools like Moi High school Kabarak with 231 students (9.8051), Sacho (became private in 2005) with 9.1680), Abuhureira Academy with 29 students (9.4317), Sheikh Khalifa Bin Zayed with 138 students (9.2826), Allidina Visram High with 129 students (9.2403), Chemelil Sugar with 73 students (8.3698), Nyahururu Elite school, 83 students (8.3658), Riara Springs Academy with 56 Students (8.3571). In the top ten, girls' only schools had 5 slots Kianda School, Precious blood Girls Riruta, Kenya high school, Bahati girls Secondary school and Bishop Gatimu Ngandu girls.

In 2006 KCSE again the single sex schools dominated the top. Most schools did well with the top school attaining a mean of 10.8840 i.e. Starehe Boys Centre. Among the top 100 (one hundred) schools, there were only 7 mixed schools. 36 girls only schools and 57 boys only. Six among the seven mixed schools only one was a public school i.e. Uasin Gishu High School with 131 students and a mean of 8.6106. The other six were private schools led by Sheikh Khalifa Bin Zayed with 144 students and a mean of 9.6736. The Aga Khan High school Mombasa with 147 students and a mean of 9.6666, Moi high School Kabarak with 238 students and a mean of 9.6218, Sacho high school with 124 students and a mean of 9.0403, Abuhureira Academy 27 students and a mean of 9.1481, Chemelil Sugar Academy with 70 students and a mean of 8.9428 (KNEC,2006)

In the top ten girls only schools had four slots i.e. Kianda School with 64 students and a mean of 10.3593, Loreto high school Limuru with 178 students and a mean of 10.3202, Precious Blood Girls Riruta with 92 students and a mean of 10.3043 and Mama Ngina Girls secondary school with 83 students and a mean of 10.0481 .

This performance has influenced the number of girls that go to Institutions of higher learning.

Education for girls is vital because women are central to development. Therefore girls' education should be great contributions that can strengthen women's role in development thus raise the quality of global decision-making. It is therefore important to identify problems which hinder women from achieving equally in education especially in the mixed schools. A lot of research has been carried out in this area of girls' performance compared to boys. Some of those who have done the research are( Eshiwani, 1983,Herz,1991, Chege \& Sifuna,2006, Nkinyangi,1980, Otite,1994, 
Kiptanui, 2000,Kitetu,1998,) All agree that mixed schools lead to better socialization than academic achievement. However, academic performance of girls outshines their male counterparts when subjected to the same learning environment. It is in this view that an attempt was made to investigate performance of girls relative to their male counterparts in mixed schools.

This study focused on the performance of girls in mixed secondary schools after four years when they sit for their KCSE. Nakuru District for a long time, before and after independence has produced good results. In 2005 in the top ten, Nakuru District had only Bahati Girls and no boy's school. In the top 50 there were three schools again Bahati Girls, Mary Mount Secondary and Rongai Boys. Municipality had no single school in the top one hundred. The first school was Menengai High school a mixed school which was position 181. It had 236 students with a mean of 7.5339. It was followed closely by Nakuru High School (a mixed school then) a National School, position 192 with 405 students with a mean of 7.4864 (KNEC, 20O5)

In the top ten schools, 2005 KCSE there was no school from Nakuru district, as Bahati Girls School moved to position 30. The first school in the District was Naivasha Girls with 97 students and a mean of 9.5979, followed by Bahati girls secondary with 81 students and a mean of 9.5185, St. Joseph's Seminary Molo (boys) with 70 students and a mean of 9.4428, Mary Mount Secondary school with 77 students and a mean of 9.3376, Rongai Boys secondary school with 88 students and a mean of 9.2840, Molo Academy (Boys) with 45 students and a mean of 8.4888, the last in top one hundred was Moi Forces Academy Lanet (Girls) with 163 students and a mean of 8.4539. Once again there was no school in the top 100 from Nakuru Municipality (KNEC, 2005).

The schools are Menengai High, Nakuru Day, Langalanga Secondary school, Afraha High School, Kenyatta Secondary, Upper Hill Secondary, Flamingo Secondary, Lanet Secondary, and Nakuru High School among others.

\section{Statement of the problem}

High girl-child participation rate in education is one of the most important talking points in any society. This is because education is one of the most effective instruments a nation has at its disposal for promoting sustainable social and economic development (GoK, 1990).Girl child education lowers infant mortality and improves health, nutrition and environmental management. In spite of massive funding on the part of the government to Education ( 2006, total public expenditure on education was 6.9 percent of GNP ,UNESCO, 2007), the KSCE results every year show 
that single sex schools are still ahead of mixed schools( KNEC, 2004,2005,2006).

In recent years, discontent with girls’ performance in various mixed secondary schools in national examinations has become widespread. Parents and social critics from all areas have vehemently complained that mixed schools are inadequately educating their children. Schools boards have been putting pressure on District Education Boards to do away with mixed schools. The Thursday Standard magazine 'On school and Career' September 2005 has been highlighting on possibility of making all school single sex to alleviate such problems. Researchers have written generally on the girl child's performance touching on topics like, Home based factors influencing Girls' performance in KCPE and KCSE, School based factors, Cultural factors and Girls’ performance, Challenges facing Girl child in the quest for Higher Education. There have also been a lot of research on girls performance in different subjects especially the sciences and mathematics (Moulton,1997,UNICEF,2004,GoK,2005a,Eshiwani,1986,1993,Chapman,20 03,Campbell,2004,Sifuna,2006,Fawe,1996,1997,Kabira,1997,Abagi,1994, Mampele,1994)

Little literature especially from sub Saharan Africa has attempted to directly asses the performance of girls specifically in mixed secondary schools. The findings were intended to cause action on part of the government and stakeholders to look for ways of promoting the girl child in mixed schools. Policy makers will use it to look into ways of empowering the girl child in a mixed school.

\section{Objectives of the study.}

To determine school - based factors, which affect girls' academic performance (KCSE) in mixed secondary schools in Nakuru Municipality.

\section{Research Questions}

The study was guided by the following research question;

a) How do school based factors affect girls academic performance

b) What possible strategies can counter the school based factors, which affect girls’ academic performance?

\section{Significance of the Study}

The study was potentially beneficial in a number of ways.

The schools in the Municipality can take the necessary actions to minimize or improve girls' poor performance. This is because they would now know the root causes of girls' poor performance in KCSE in their schools. 
The study would benefit the Quality Assurance and Standard Officers who can take curative measures to the problems and this would yield good fruits not only to Nakuru Municipality but also to the District, Province and Nation as a whole. Education planners will be able to make decisions about female education e.g. converting mixed schools to single sex schools.

\section{Basic Assumptions of the Study}

The following assumption guided the study.

a) The information given by the respondents is what they felt are the causes of poor performance of girls in mixed schools.

b) Both boys and girls were exposed to the same learning environment in terms of curriculum.

c) Both boys and girls came from similar backgrounds.

d) Both boys and girls on average scored the same marks in KCPE and therefore have some intellectual capacity.

e) Both get the same learning opportunities in school.

f) Girls in mixed schools do not perform as well as boys in the same school.

\section{Limitation of the study}

This study was conducted with the following limitations in mind:-

a) The study was limited to only 6 schools in Nakuru Municipality. The findings of the study could not therefore be really generalized to the entire District or Province.

b) Resources and time were important yet they were limited since time and money could not allow the researcher to reach all the schools. This was due to the fact that the researcher was collecting, analyzing and compiling the information while still undergoing the normal school attendance and teaching.

c) The financial limitation comes in due to the fact that the researcher was self-sponsored. There was typing, traveling and binding expenses.

d) Due to time limitation, the researcher was not able to trace the students who had already sat for KCSE in the previous years in the municipality whose responses would have been crucial to the research.

e) The study relied on self-report from Head teachers, teachers, form four students and it was not be possible to check the validity of their declarations against other measures in their respective institutions. Reliance on self-report can be problematic and may threaten the validity of the findings. It is possible that some participants were biased in their replies, and in replying honestly to certain questions. Triangulation of the research methods/Instruments addressed the limitation. It was however hoped that the results were to benefit all the education stakeholders. 


\section{Theoretical Framework}

The current study was based on Pearson's theory, where society views all activities that are carried out to be based on social roles and interactions of men and women. This is an assumption of gender roles as dictated by society. The society seems to have ultimate authority on the precise nature of what women and men actually do, and their real contribution to production and reproduction which turns out to be biased against women according to (Orodho 2004). This theory argues that because of biases, the performance of women and men is affected in nearly all spheres of life e.g. business, education, and environmental conservation and development projects. Pearson's gender relations' framework was found appropriate for this study because it emphasizes the various social, cultural and economic norms and standards, which must be considered when girls or females take the opportunities to participate in social activities such as education.

\section{Definition of Central terms}

Mixed Schools - schools where both boys and girls learn together as opposed to single - sex schools.

Performance - Status of a pupil with respect to attain knowledge on skill as compared with other pupils and with other schools adopted standards.

Education - Any process, either formal or informal, that shapes the potential of a maturing organism. Informal education results from the constraint effect of environment and its strength in shaping values and habits cannot be overestimated. Formal education is a conscious effort by human society to import the skill and modes of thought considered essential for social functioning.

Mean grade - This is the average grade of all subjects done in this case at KCSE.

KCSE - This is the Kenya Certificate of Secondary Education, an exam done at the end of four years in Secondary Education.

KCPE - This is the Kenya Certificate of Primary Education; an exam done at the end of 8 years primary Education.

Governing Board - Legal body entrusted with the responsibility of managing secondary schools and tertiary institutions in education like teacher colleges.

School - An organized group of pupils pursuing desired studies at desired levels and receiving instruction from one or more teachers frequently with the assistance of other employees and officers e.g. Head teachers and Inspectors. 
Teacher - A person employed in an official capacity for purposes of guiding and directly the learning experienced of pupil in an educational institution whether private or pupil.

Attitude - Refers to readiness to react towards or against some situation, a person or thing in a given manner for example with love, hatred or fear or resentment - to a particular degree of intensity.

\section{Literature review Introduction}

The purpose of this chapter was to review literature related to the problem content. In this case, the literature was reviewed from various books and also studies carried out by different researchers both locally and internationally. School based factors affecting girls' performance in Education are many and varied according to the existing literature. They are classified into the following categories.

\section{Cultural Constraints}

Several authorities have discussed at varying lengths the cultural constraints as they operate to limit education for girls in the world.

Dale (1969, 1971, and 1974) in his studies noted that girls in mixed schools perform poorly because of societal attitudes where society does not advocate boys and girls living together. Dale however, feels that education should be mixed because according to him, both boys and girls were more satisfied with mixed schools, seeing it as amore "natural" environment and feeling it helped their relationships with the opposite sex. Similarly Hannan \&Shortfall (1991) found that male and female ex -students of mixed schools in Ireland were more positive about the personal and social development aspects of their schooling. Dale further argues that if mixed schools are relaxed in giving homework, which leads to poor performance, then boys and girl's performance would be affected. This is however refuted by a research done by Kitetu (1998) who did a research project from 1995 to 1998 in secondary school classrooms in Kenya. The research unearthed, cultural specific and historically located gendered classroom behaviour and practices. The research showed that girls and boys engaged in different activities within the same lesson, with girls showing minimal involvement in activities requiring physical exertion. There was also teacher's differential treatment of girls and boys, but in this case teachers were harsh on boys and very gentle with the girls. While this has been noted in other research such as 'task demarcations' and teachers' differential treatment by gender, the study was underpinned by society's cultural beliefs. There is a Kenyan cultural belief that boys should not be 'softened'. They are expected to be tough, active and brave while girls are often treated as 'soft'. As such, teachers' 
treatment of boys and girls in these classrooms reaffirmed gender in accordance with cultural norms which define masculinity and feminity.

Aseka (1986) in her research, 'A review of literature on factors affecting girls' performance in mixed second schools' says “....in all textbooks .... Whenever portrayed, girls are identified with traditional values and ways of life. It portrays boys as stronger, more incentive, and active, thus developing biased attitudes among the children and leading to consequent withdrawal of girls". In a majority of classrooms observed, art featured more photos and graphics of male authors and heroes than of females. School texts, art and teaching aids that focus on men as being the leaders, thinkers and creative minds can condition girls that are lower than their potential.

This shows the disparity of treatment between boys and girls, something has to be done to create similar ideas Maleche (1972) and Eshiwani (1983) recognize the fact that for students who are not boarders, greater demands are made on girls to assist with household chores e.g. taking care of their younger siblings, fetching firewood and water. The boys are therefore likely to perform better. As Carnoy (1986) aptly says, gender is regulated and policed by rather social norm, but this does not mean they (men and women) are reduced to automate, programmed by early socialization to repeat forever the appropriate gender behaviour. They are conscious agents who may engage in acts of transgression, subversion and resistance. As active producers rather than passive producers of gendered behaviour, men and women may use their awareness of gendered meanings that attach to particular ways of speaking and acting to produce a variety of effects. In short, teachers may be able to encourage their students to resist gender notions that interfere with their learning. Special effort therefore need to be employed to cultivate girls' interest in education and provide an environment that will ensure their full participation and achievement in education. Several authorities have discussed at varying lengths the cultural constraints as they operate to limit education for girls.

\section{Structural Constraints}

To understand the nature of structural constraints in the Education system that hinder advancement of women, it is important to understand the place of women in Education as was stipulated by some of the early educators as the present Education systems have borrowed greatly from them.

A historical procedure was set of boys being favoured for school attendance. The trend was supported by the emphasis on early marriage for girls in indigenous Africa Societies and the lack of attentive role models to which girls could aspire. First mission schools were therefore for boys. 
These were sentiments raised by Judy Wakhungu- Executive Director of the African Centre for Technology (Acts). She is one of the few women geologists. She says that apart from lack of role models, they lack knowledge on career opportunities. "Many girls find the science classroom chilly and male dominated. With this kind of observation, we can tell then why it is important for the girls to be separated from the boys. The year 2005 has seen the standard magazine 'school and career' highlighting opposition to mixed schools. Principals, school and education boards wanted separate institutions for boys and girls at secondary level. Some reasons are to improve girls' performance. In a special Report - 'Splitting schools' (The standard September 22, 2005). It said separation is the road to liberation of the sexes It further says in most mixed schools girls rarely ever score a grade higher than a B. Many girls in mixed schools have the mentality that University education is the preserve of men and only if they are taught alone would they be confident..

Women are underrepresented in parliament where key decisions are made and account for just $8.3 \%$ of the seats. At the local authorities, the picture is not any rosier.

In 2004, the National Commission on Gender and Development was established through an Act of Parliament to coordinate, implement and boost gender issues and to advice the Government and other organization. This has however not been achieved. If this is the case then a lot has to be done to encourage the girls to do even better, the numbers at the top is still too small to help solve matters. It is therefore clear that although women comprise 51 $\%$ of Kenya's population and more than half of the labour force, their efforts are not adequately captured in national accounts. The articles continue to say that it is in education where Gender inequality is most acute. It is not compulsory for children to get early childhood education to quality for primary school, more so for girls. Although gender disparity in enrolment is low, the national average of $35 \%$ is poor and provincial differences glaring with arid and semi-arid areas and slums recoding the lowest. The traditional attitude, which discourages girls from mathematics and sciences, complied with limited facilities for technical subjects in girls' schools are partly to blame for the trend. The Government has appointed women to key positions but they are still relatively few. There are few business leaders or women in higher public office in most particular societies. This is often reflected in gender-biased curriculum therefore, girls may not be aware of the available opportunities or the challenges to success. It is important to note that girls are in particular need of role models and guidance on their choice of studies and careers. In girls' schools, most teachers and administrators are women. These role models may inspire young girls to become change agents and overcome social barriers. Interacting with female role models and receiving personal 
encouragement and advice help girls to succeed in life (Lehorer, 2000). In Kenya, as of June 2003, the proportion of women in the Judiciary was at $36.4 \%$ and most in the rank of chief magistrate and below. With political considerations, ethnic balancing and experiences being key determinants to appointment, women lose out even where they merit.

Another structural problem has been the changing orientation of Kenya's Education, system in the 1980's towards a greater emphasis on science, mathematics and technical subjects, combined with the failure to provide girls with access to proper training programmes, but clearly girls have fewer opportunities to benefit from as their subjects are mainly arts. Okonkwo (1983) observes that parents and teachers discourage female students from studying science subjects which they stereotype as masculine and encourage them to study arts subjects instead. He also observes that the tendency for sex-linked polarization of subjects is higher in mixed schools than in single- schools i.e. more girls tend to take sciences in single-sex secondary schools and vice-versa. Some research findings however suggest that girls do better in certain subject areas such as mathematics and science when boys are not in class (Robinson\& Gillibrand, 2004). In one of the earlier studies, Jimenez \&Lockheed (1989) assessed the performance of 3,265 eighth grades in single sex and mixed schools in Thailand. Girls in girl-only schools scored higher in mathematics. Boys scored higher than girls in mixed schools' mathematics classes. These difference were largely because of peer effects. This is likely to be due to the fact that the boys in class challenge them. Often, students are exposed to syllabi and textbooks that ignore women roles and contribution to society. Obura (1985) observes that in mixed schools, girls under- achieve in every examinable subject as compared to boys. She attributes the phenomenon of under - achievement to withdrawal and non-involvement on the part of the girls as they proceed up the educational scale. This she argues is as a result of the unsuitable learning environment for girls in schools.

It holds that even though boys and girls are exposed to the same curriculum, it portrays boys as stronger, more inventive, more active sex, thus developing biased attitudes among the children and leading to the consequent withdrawal of the girls. Eshiwani (1976) argues that girls under achieve in science and maths because the school through the teachers provides different treatment and experience for boys and girls in science and math's by encouraging the boys to pursue sciences and giving more help to the boys than the girls. This case maybe more serious in mixed schools because singling out the boys under such circumstances maybe more devastating to the girls. This sex role stereotyping sows seeds of differential achievement. However, research shows that in girls' only classrooms, they are engaged in learning mathematics and science most of the time, and they 
show cooperative learning behaviors and identify better with their female classmates than when in mixed classrooms. Most teachers of mathematics do not believe that girls can achieve as well as boys in mathematics. The previous research by Eshiwani (1974) shows that in general, girls develop negative attitude and little aspirations towards mathematics and this tends to affect their performance. The culture in mixed schools may discriminate against female teachers and girls' students. This can be the real, although often unintended, impact of education systems that have been shaped and managed largely by men. Without a conscious effort to make the school empowering and valuing of girls, as well as boys, discrimination can hurt girls. It can impair their self-confidence and achievement as well as lower their career and education goals. This is however disputed by other studies which that there are no differences in what girls and boys can learn but there may be different ways to engage and teach girls as compared to boys (Jimenez \& Lockhead , 1989).

Critics of single sex education however see things differently. They argue that girls' only schools are unnatural social settings which isolate girls from boys. In well managed mixed schools, boys and girls learn to respect and value each other idea. They learn to listen and communicate with each other. Isolating girls and boys in single-sex schools is considered a barrier to them developing the effective inter-personal skills they will need to function as grownups in their society (Lehrer, 2000). They continue to say that single sex schools can lead boys and girls not to witnessing the ideas, talents and skills of the other sex. This can reinforce the existing gender bias in society. In addition, some contend that creating schools for girls suggests girls have problems and need special attention. This may cause girls to think less positively of themselves.

When the Minister for Education Science and Technology was releasing results for KCSE 2004 (KNEC,2004) he noted that the number of girls taking Physics and vocational subjects except home science was low. In 2002, only 15, 312 girls took Physics compared to those who took Biology $(87,141)$ and Chemistry $(87,725)$. The total number of girls was 91, 649. In 2003, 16,094 girls took Physics, 91,108 took Biology and 91,108 Chemistry respectively. When releasing the KCSE results for 2005 students (KNEC, 2006) the acting Education Minister Dr. Noah Wekesa said girls performance in English, Kiswahili, Home Science, Art and Design, Woodwork, German, Music and economics was rated as better than of boys. However, boys had better performance than their female colleagues in all the other subjects.

Again in 2006 KCSE (KNEC, 2006) the girls beat the boys in Kiswahili, Biology Science, Home Science and Music. The boys led the rest. 
Finally, girls often become victims of circumstances when they fall pregnant. Eshiwani (1985) observes that $10 \%$ of female drop - out is due to pregnancy. Education system recommends expulsion of such students and so they are forced to drop out. This is further argued by Education stakeholders (KNEC, 2005). Mrs. Mary Ndegwa, the principal of Kilgoris girls Secondary School says the setting up of Kilgoris Girls School has borne fruit "Pregnancy that was rampant when the girls were in mixed schools has gone down drastically" she says last year, a girl scored B- in KSCE at Kilgoris girls, a feat no girl had ever accomplished in the Districts mixed schools. They maintained that instead of seriously doing academic work, the girls are more concerned with love affairs and consequently perform poorly while boys are not very much affected academically. In school and career. (The Standard, September 15, 2005) several Education stake holders were interviewed on their mixed schools, while some supported the system majority were against it with reference to girls performance. Richard Ouma, the Principal of St. George's Sianda (Kisumu) mixed Secondary admits that love relationships between girls and boys in mixed schools are a destabilizing factor. Student's performance deteriorated if they spend a lot of time on the affairs.

The principal says some girls do not do assignments but instead wait for their lovers to do so and they just copy. How would such a girl perform at the end of four years? He however says that mixed schools can be considered good training ground for girls to be bold and confident.

Eshiwani (1983) in "Who goes to University in Kenya" found out that majority of girls who joined University came from single-sex schools. Ironically most of the girls who become pregnant during their studies were from single-sex schools. Professor Owino Riew - school and career (The standard 15, March 2005) agrees with this he says there is "less thirst" for the opposite sex in mixed schools. He explains that boys and Girls are used to one another unlike in single sex schools". This implies they are less socially developed in single sex schools but further proves that in Secondary schools, single sex schools are academically more superior.

In poorly managed schools, there is the risk of male teachers and boys physically or sexually abusing the girls. There are also other forms of violence, intimidation and embarrassment. It has been argued that male teachers take advantage of their students. This problem is however not a preserve of mixed schools as it also takes place in girls only school. However, in this case the male teachers see the male students as their competitors as they tend to have love affairs with the girls as they can provide the female students with money and other material benefits.

Mixed schools that lack separate toilets for girls or have long lines of latrines without privacy humiliate girls and put them at risk. Day-to-day 
harassment, verbal abuse and bullying can build up and destroy girls' ability to concentrate and their joy of coming to school. These are less in girls' schools. According to some studies, in girl-only learning environment girls are more successful female role models. The top students in all academic subjects and the leaders in sport and extra-curricular activities are girls. Building onto this, some research indicates that adolescent girls feel better themselves in many ways when they are educated in girls' schools as opposed to mixed schools (Strabiner, 2000)

School boards cite indiscipline as the reason for their rejection of mixed Schools. School and career (The Standard September 15, 2005) says that Indiscipline cases in mixed school have increased and this has created a lot of fear among the girls in mixed schools. This is because their schoolmates from whom they can seek refuge in times of danger turn out to be their assailants like the case of St. KIZITO in Meru in the early 90's. However indiscipline is not the preserve of mixed schools, single sex schools are equally affected.

\section{Summary}

The literature review has tackled cultural constraints affecting girls performance in education e.g. the belief that education can only help ruin the girls from what they are expected to be by society, positive attitude towards boys by the teachers. It further states that girls shy away from doing competitive courses.

The structural constraints can be understood from the point of some of the early educators who had boys favoured for school attendance and recommended early marriage to girls. The concept of women empowerment is yet to be institutionalized and the businesses they dominate have systematically been pushed to the periphery. There has been a general belief that girls can do as well in Maths and Sciences like the boys. The girls have believed this to be true and so look on boys as superior. The reviewed studies have however not investigated the actual social, cultural school based factors which affect girls, academic performance in mixed secondary schools. This is the problem which the current study investigated in mixed secondary schools in Nakuru Municipality.

\section{Research methodoly}

This section describes the research methodology that was used in the study. It explains the research design, target population, sampling procedure, sample size, research instruments, validation procedures, data collection and analysis procedures. 


\section{Research design}

The study adopted a mixed method design an approach to inquiry that combines or associates both qualitative and quantitative forms (Creswell, 2007).It is more than simply collecting and analyzing both kinds of data; it also involves the use of both approaches in tandem so that the overall strength of a study is greater than either qualitative or quantitative research (Creswell \& Plano Clark, 2007).

\section{Target Population}

The target population for this study was 12 public mixed secondary schools within Nakuru Municipality. From the sampled schools, an equal numbers of students were selected from form four classes in each school totaling 160. Sixty (60) teachers were included in the study and six (6) head teachers.

\section{Location}

The study was carried out in Nakuru Municipality, of Nakuru District because the problem of girls poor academic performance in KCSE in mixed secondary schools has been phenomenal as evidenced by the poor performance mentioned. Therefore there is a need to carry out study to determine the factors responsible and for this to establish the possible strategies that the secondary schools use to address this challenge.

\section{Sample and Sampling Procedure}

A sample is a small proportion of a target population. Sampling means selecting a given number of subjects from a defined population as a representative of that population. Any statement made about the sample should also be true to the populations Prewitt (1980). According to Napa (1997) a research should select a sample large enough to improve the likelihood of obtaining results that are similar to what would be obtained using the entire population. A 50\% sample is recommended for populations that run in hundreds for population that runs in thousands, $5 \%$ to $20 \%$ may be drawn. This was the convenient sample for the study.

The study sample was six (6) schools, six (6) head teachers, sixty (60) subjects teachers, sixty (60) girls. The schools included in the study were selected through simple random sampling techniques, which gave the six (6), head teachers who participated in the study. This technique was used to select these schools because these institutions are of similar characteristics i.e. mixed schools. Purposive sampling technique was used to select the ten (10) subject teachers in every school. The ten (10) subject teachers were those examined in KCSE: Maths, English, Kiswahili, Biology, Chemistry, Physics, History, Geography, Business Studies and Agriculture. The ten (10) 
girls from every school that were included in the study were selected by using simple random sampling technique because the performance of such students similar i.e. poor performance with a mean grade of $\mathrm{C}$ - in almost all the school in the sample.

The total number of respondents included in the study were as shown in table 1.2 below.

Table 1.1: Total number of respondents

\begin{tabular}{|cc|}
\hline RESPONDENTS & NUMBERS \\
\hline Schools & 6 \\
\hline Head teachers & 6 \\
\hline Subject teachers & 60 \\
\hline Form four students & 60 \\
\hline Female Students (girls) & 6 \\
\hline
\end{tabular}

\section{Research Instruments}

Two types of instruments were used for the study; questionnaires and interview guide.

\section{Questionnaires}

Enables you to collect more information from a big number of people. Most commonly used method when respondents can be reached and are willing to co-operate. Questionnaires were preferred for this study because according to Gay (1981) descriptive date are typically collected through questionnaires to be administered.

\section{Students Questionnaires}

Sixty (60) students were issued with questionnaires to answer. The students were form fours so it was appropriate for them to answer the questionnaires.

\section{Teachers Questionnaires}

Questionnaires were administered to form four subject teachers. They are conversant with what goes on in class and outside classrooms,

Achola and P. (1987) have outlined the suitability of using questionnaires in a study

a) Large coverage of population can be realized with little time, personnel or cost.

b) Anonymity of the respondents filling the questionnaires may help them to be honest in their answers.

c) Avoid bias due to characteristics of interviews

d) Allows respondents time on answering questions to avoid hasty responses. 


\section{NB The questionnaire were to be designed to obtain such information as; school based related to the objective of the study.}

\section{Interview}

Kathuri (1993) defines an interview schedule as an outline of questions that form a basis for and guide the interviewing process. The schedule provides a structure that aids in obtaining the necessary information efficiently and in a business-like atmosphere. Enables you to gather in-depth information, to counter check/confirm the information obtained through questionnaire.

\section{Head teachers' Interview schedule}

The interview guides were used to respond to verbal responses from the head teachers of the six selected schools regarding poor performance of girls. The researcher went for this because the head teachers also teach the students. They are the ones who collect fees so they know the financial problems as they interact with parents personally. They are also directly involved with disciplinary cases involving the students.

\section{Piloting}

Once the questionnaire has been constructed, it should be tried out in the field. The questionnaires were pre-tested to a selected sample of four schools outside the selected samples in Nakuru Municipality. Piloting ensures that research instruments are stated clearly and have the same meaning to all respondents (Mugenda and Mugenda 1999; 186).

\section{Validity of the Instruments}

Validity of the instrument to be used for data collection was determined through content validity procedure by seeking expert judgment and discussion with the supervisors and other professionals.

\section{Reliability of the instrument}

Reliability of the instrument concerns the degree to which a particular measuring procedure instrument gives similar results over a number of repeated trials.

A test - retest or coefficient of stability method was used to estimate the degree to which the same results could be obtained with a repeated measure of accuracy of the same concept in order to determine the reliability of the instrument. It was assumed that responses to the two tests would be very similar because the latter reflects the same thing (content) for respondents. 
Score obtained by each respondent on the first and second test was quite close. If they were not then the instruments would have been of low reliability.

In order to test reliability of the instrument in the study, following steps were stipulated

a) The developed questionnaire was given to a few identical subjects for the study in two mixed schools in Naivasha Municipality.

b) The answered questionnaire was scored manually.

c) The same questionnaires were administered to the same group of subjects after a period of two weeks.

d) The questionnaire responses were score manually

e) A comparison between answers obtained in b and d above were made.

A Pearson's product moment formula for the test - retest was employed to compute the correlation coefficient in order to establish the extent to which the contents of the questionnaire are consistent in eliciting the same responses every time the instrument is administered.

\section{Data Collection Techniques}

The researcher obtained a research permit from the Ministry of Education headquarters at Jogoo House (Nairobi) to seek for permission to visit schools as they fall under it. From the Ministry, the researcher got permission from the District Education Officer, Nakuru District to visit Schools. The researcher then visited six secondary schools in Nakuru Municipality informing them about this study and organizing with school heads to meet the teachers and students. Lastly, there is the actual visit to schools teachers and students in samples schools and interview session with him. The researcher gave them instructions on how to answer the questions.

\section{Data Analysis}

The data collected was subjected to mixed method analysis approach. The sample size was 132 which can allow the generalization of the study. The researcher used wave analysis to determine response bias that is, the researcher examined returns on select items week by week to determine if average responses change (Creswell 2007). Those who returned surveys in the final weeks of the period were considered nearly all non-respondents. Descriptive statistics like mean, mode, frequencies, percentages and charts were used. Data was collected by means of questionnaires and interview schedules. 


\section{Data presentation and analysis}

The principal guiding factor in that data analysis presented in this chapter was the study objectives highlighted as follows.

a) To determine if there is a relationship between girls' poor performance and school based factors.

b) To determine the possible strategies that can counter the factors, which affect girls' academic performance.

The collected data was analyzed using descriptive statistics. Frequency distribution tables and percentages were used to help in cross tabulation of data. According to Orodho (2004), tables and more so dummy tables describe statistical results more clearly and economically than words.

\section{Demographic Data of Study participants}

There were five head teachers out of the six intended who participated in the study. Table 4.1 presents the age, gender, academic and professional qualifications of the head teachers who participated in the study.

Table 4:1Head teacher's frequency

\begin{tabular}{|c|c|c|}
\hline AGE BRACKET & FREQUENCY & PERCENTAGE \% \\
\hline 31-40 YRS & 3.0 & 60.0 \\
\hline 41-50 YRS & 1.0 & 20.0 \\
\hline 50 YRS AND ABOVE & 1.0 & 20.0 \\
\hline TOTAL & 5.0 & 100.0 \\
\hline \multicolumn{3}{|c|}{ ACADEMIC QUALIFICATIONS } \\
\hline Dip & 1.0 & 20.0 \\
\hline BA/BSc With PGDE & 1.0 & 20.0 \\
\hline B.ED & 3.0 & 60.0 \\
\hline TOTAL & 5.0 & 100.0 \\
\hline \multicolumn{3}{|c|}{ EXPERIENCE } \\
\hline 6-10 YRS & 1.0 & 20.0 \\
\hline 11-15 YRS & 1.0 & 20.0 \\
\hline 16 YRS and above & 3.0 & 60.0 \\
\hline TOTAL & 5.0 & 100.0 \\
\hline \multicolumn{3}{|c|}{ SCHOOL } \\
\hline DAY SCHOOL & 4.0 & 80.0 \\
\hline FULL BOARDING & 1.0 & 20.0 \\
\hline TOTAL & 5.0 & 100.0 \\
\hline \multicolumn{3}{|c|}{ STREAMS } \\
\hline SINGLE STREAMED & 1.0 & 20.0 \\
\hline DOUBLE & 1.0 & 20.0 \\
\hline TRIPLE & 3.0 & 60.0 \\
\hline TOTAL & 5.0 & 100.0 \\
\hline
\end{tabular}

Source: Head teacher's questionnaire

Their age and academic qualifications are as given in the table. The table shows most of the head teachers, $60 \%$ of them are B.ED holders the 
best requirement for secondary education. The years of experience are quite high-16years and above. This makes them better in handling the girls in school having dealt with them for long. Majority of them, $60 \%$ are in triple streamed classes a sign that majority deal with big numbers which is likely to lead to neglect of other students, especially girls who may need special attention.

The study also involved subject teachers. 55 teachers out of the initial sixty from the six schools were involved in the study. Their demographic data involved age, academic qualifications and experience. This is given in table 4.2.

Table 4.2 Teachers Frequency

\begin{tabular}{|c|c|c|}
\hline AGE BRACKET & FREQUENCY & PERCENTAGE \% \\
\hline 20-30 YRS & 4.0 & 7.3 \\
\hline 31-40 YRS & 36.0 & 65.5 \\
\hline 41-50 YRS & 15.0 & 27.2 \\
\hline TOTAL & 55.0 & 100.0 \\
\hline \multicolumn{3}{|c|}{ QUALIFICATIONS } \\
\hline DIP & 13.0 & 23.6 \\
\hline BA/BSC with PGD & 15.0 & 27.0 \\
\hline B.ED & 22.0 & 40.0 \\
\hline M.ED & 4.0 & 7.3 \\
\hline MA/MSC & 1.0 & 1.8 \\
\hline TOTAL & 55.0 & 100.0 \\
\hline \multicolumn{3}{|c|}{ EXPERIENCE } \\
\hline BELOW 1 YRS & 2.0 & 3.6 \\
\hline 1-5 YRS & 2.0 & 3.6 \\
\hline 6-10 YRS & 6.0 & 10.9 \\
\hline 11-15 YRS & 27.0 & 39.2 \\
\hline 16 YRS and above & 18.0 & 32.7 \\
\hline TOTAL & 55.0 & 100.0 \\
\hline \multicolumn{3}{|c|}{ STREAM } \\
\hline TRIPLE & 40.0 \\
\hline DOUBLE & 11.0 & 72.7 \\
\hline SINGLE & 4.0 & 7.3 \\
\hline TOTAL & 55.0 & 100.0 \\
\hline
\end{tabular}

Source: Teachers Questionnaire

Most of the teachers fell in the age bracket of 31-40 years i.e. $65.5 \%$. $23.6 \%$ of them were diploma holders, $27.2 \%$ have BA /BSc with PGD while $40 \%$ were B.Ed holders. The remaining $1.8 \%$ had Masters Degree. With majority having B.Ed, this was a good sign as that is what is needed for a secondary education. 
Majority of the teachers $-49.1 \%$ have an experience of between 11$15 y r s$ and another 3.6 below 1 years' experience only $32.7 \%$ have an experience of 16 years and above. Most of the teachers therefore have enough experience a good sign that they can help deal with student's problems. $72.7 \%$ of the teachers are in Triple streamed schools, $20 \%$ in double stream while 7.3 in single streams. This is an indicator that the teachers have their hands full. The study also involved 60 girls all from four classes.

\section{Relationship between poor performance and school based factors}

The first objective of the study was to find out the relationship between poor performance and the school based factors. Table 4:3:1 shows respondents (teachers) view on the school based factors.

Table Teachers on the school based factors

\begin{tabular}{|c|c|c|c|c|}
\hline \multirow[t]{2}{*}{ School Based Factors } & \multirow[t]{2}{*}{ No. } & \multicolumn{2}{|c|}{ Min. Max. } & \multirow[t]{2}{*}{ Mean } \\
\hline & & Yes & No & \\
\hline SB- Instructional method used same & 55 & 1 & 2 & 1 \\
\hline SB- Who are more indiscipline & 55 & 1 & 2 & 1 \\
\hline SB- All teachers qualified & 55 & 1 & 2 & 1 \\
\hline SB-Boy/girl relationship & 55 & 1 & 2 & 1 \\
\hline SB- Boys have positive attitude towards girls & 55 & 1 & 2 & 1 \\
\hline SB- Equal adequate guidance and counseling & 55 & 1 & 2 & 1 \\
\hline SB- Who perform better in class & 55 & 1 & 2 & 1 \\
\hline SB- Do you have discipline cases & 55 & 1 & 2 & 1 \\
\hline SB- Enough learning facilities & 55 & 1 & 2 & 1 \\
\hline SB- Does mix nature of school bring discipline cases & 55 & 1 & 2 & 1 \\
\hline SB- Female teachers have special relationship with girls & 55 & 1 & 2 & 1 \\
\hline SB- Learning facility lacking & 55 & 1 & 2 & 2 \\
\hline SB- Teaching in single sex & 55 & 1 & 2 & 2 \\
\hline SB- Who are selected with high marks & 55 & 1 & 2 & 2 \\
\hline SB- KCPE pass mark same & 55 & 1 & 2 & 2 \\
\hline SB- Mixed schools bring about socialization & 55 & 1 & 2 & 2 \\
\hline SB- Who are more affected by relationship academically & 55 & 1 & 2 & 2 \\
\hline SB- Boys academically capable & 55 & 1 & 2 & 2 \\
\hline SB- Preferred school & 55 & 1 & 2 & 2 \\
\hline
\end{tabular}

\section{Key}

\section{SB - School based}

The first column were the school based factors considered in this study, the second column was the sample size of the respondents in the objectives (teachers), the third column represented the minimum of the response which was coded to represent yes, the forth column represented the maximum of the response which was coded to represent No. The fifth column represented the mean between the minimum (yes) and the maximum (No) whereas the last column was the standard deviation.

Out of the teachers interviewed 30\% disagree that boys are more capable academically, $16.4 \%$ strongly agree, $23.6 \%$ agree while 29.1 strongly disagree. It therefore comes out clearly that it's not boys who are academically bright but it is girl's circumstances that make them not do well. 
In class $87.3 \%$ say boys perform better than girls while only $12.7 \%$ support the statement. Instructional methods used in class are the same 98.2 $\%$ agree while $1.8 \%$ says no. Students are given same teaching methods in mixed schools so one can't say; they don't do well due to different teaching methods.

Only $29.1 \%$ agree that admission for boys and girls is the same as 70.9 say boys go with higher marks. If this is so then there can be no fair competition thus could be done to Ministry of Education lowering cut off for girls.

Boy girl relationship seems to be a factor affecting the girls' performance as $90.0 \%$ concur with the fact and only $9.1 \%$ disagree. To make matters worse $81.8 \%$ say these relationships affect girls more while only $18.2 \%$ boys get affected. Girls are more vulnerable and tend to get wholly involved unlike boys who will still do their schoolwork.

The mixed nature of the school brings discipline cases $70.9 \%$ say so as opposed to $29.1 \%$ yet the boys are more in disciplined with $98.2 \%$ confirming this only $1.8 \%$ say girls are in disciplined therefore cannot be said to attribute to poor performance of girls as they are not in disciplined.

Out of the teachers questionnaires $87.3 \%$ of them say the students are given equal guidance and counseling opportunity while 12.7 say No, so we cannot say girls are denied counseling.

Most schools according to $74.5 \%$ of the teachers have enough learning facilities only $25.5 \%$ say they are not enough. We can therefore not say that in mixed schools lack of learning facilities make girls not perform well. Neither can they claim that the teachers are not well trained $-96.4 \%$ say teachers are well trained only $3.6 \%$ deny this.

It is worth noting that $54.5 \%$ say female teachers have special relationship with the girls as opposed $45.5 \%$. This should be a motivating factor to the girls as they get confidence and see them as role models.

According to the teachers several school-based factors do affect girls KCSE performance. The head teachers on the other hand responded to the following questions.

a) Have you been a head teacher in a single sex- school?

b) Do you prefer heading boy, girls or mixed schools?

c) Which combinations of schools do you prefer?

d)Are the minimum KCPE intakes for boys and girls the same?

e) Does this intake have any direct results on performance?

f) Are there boy/girl relationships in your school?

g) Do you have discipline cases in the school?

h)Have you had cases of male teachers getting involved with female students? 
To respond to the above questions, the researcher arrived at the following responses;

Table 4:3.2

\begin{tabular}{|c|c|c|}
\hline \multicolumn{2}{|c|}{ BEEN A HEAD TEACHER IN SINGLE SEX SCHOOL } \\
\hline RESPONSE & FREQUENCY & PERCENTAGE \% \\
\hline YES & 3 & 60 \\
\hline NO & 2 & 40 \\
\hline TOTAL & 5 & 100 \\
\hline EXPERIENCE BETTER THAN MIXED SCHOOL \\
\hline RESPONSE & FREQUENCY & PERCENTAGE \% \\
\hline YES & 2 & 40 \\
\hline NO & 3 & 60 \\
\hline TOTAL & 5 & 100 \\
\hline SCHOOL PREFERENCE OF TYPE OF SCHOOL \\
\hline BOYS & FREQUENCY & PERCENTAGE \% \\
\hline GIRLS & 1.0 & 20.0 \\
\hline MIXED & 1.0 & 20.0 \\
\hline TOTAL & 3.0 & 60.0 \\
\hline
\end{tabular}

Source: Head teachers questionnaires

Out of the Head teachers interviewed, $60 \%$ of them have headed single sex school as opposed to $40 \%$ who have no experience in single sex schools. Again $60 \%$ of them agree that experience in mixed schools is better than in single sex schools. An indicator that mixed schools are better and just a lot more should be done. Majority of the head teachers- $60 \%$ prefer heading mixed schools. On preference to head different categories of schools table 4:3:3.

Table 4:3:3 preferred combination of school

\begin{tabular}{|c|c|c|}
\hline SCHOOL & FREQUENCY & PERCENTAGE \% \\
\hline MIXED SCHOOL & 4 & 80 \\
\hline NONE & 1 & 20 \\
\hline TOTAL & 5 & 100 \\
\hline
\end{tabular}

Source: Head teachers' questionnaires

KCPE intake for boys and girls same.

NO $-100 \%$

Boys taken with high marks $100 \%$

Most head teachers 80\%prefer heading mixed schools while only $20 \%$ prefer the single sex school an indicator that mixed schools are popular. The challenge on the KCPE intake for boys and girls was responded to as follows.

$100 \%$ of teachers interviewed agree that KCPE intake for boys and girls is not the same and concur that boys are taken with higher marks and 
the reason for this is indicated in TABLE 4:3:4. This is a sign that boys who are picked to go to high school have high marks than girls.

Table 4:3:4

Reason for boys being taken with high marks

\begin{tabular}{|c|c|c|}
\hline RESPONSE & FREQUENCY & PERCENTAGE \% \\
\hline BOYS DO BETTER THAN GIRLS & 1.0 & 20.0 \\
\hline MORE BOYS ENTRANCE AT KCPE LEVEL & 2.0 & 40.0 \\
\hline GIRL CHILD MAINSTREAMING & 2.0 & 40.0 \\
\hline TOTAL & 5.0 & 100.0 \\
\hline
\end{tabular}

Source: Head teachers' questionnaires

On whether the intake has any direct results on performance, table 4:3:5 shows this. $60 \%$ of the head teachers agree that intake has direct result on performance as opposed to $40 \%$ who cannot relate them. Indeed those taken with high marks tend to do better.

Again $80 \%$ of the head teachers agree that boys tend to do better while only $20 \%$ don't agree and on reasons $60 \%$ says that the influence is the major cause of this kind performance and $40 \%$ say environment.

Table 4:3:5

\begin{tabular}{|c|c|c|}
\hline \multicolumn{3}{|c|}{ INTAKE HAS DIRECT RESULTS ON PERFORMANCE. } \\
\hline RESPONSE & FREQUENCY & PERCENTAGE \% \\
\hline YES & 3 & 60 \\
\hline NO & 2 & 40 \\
\hline TOTAL & 5 & 100 \\
\hline \multicolumn{2}{|c|}{ WHO PERFORMS BETTER } \\
\hline BOYS & 4 & 80 \\
\hline GIRLS & 1 & 20 \\
\hline TOTAL & 5 & 100 \\
\hline REASONS FOR BETTER PERFORMANCE \\
\hline ENVIRONMENT & 2 & 40 \\
\hline INFLUENCE & 3 & 60 \\
\hline TOTAL & 5 & 100 \\
\hline
\end{tabular}

Source: Head teachers questionnaires

The challenge on boy girl relationship table 4:3:6 they agree that this is very rampant and $80 \%$ agree while $20 \%$ disagree. Again it affects girls' academic performance as opposed to boys. On discipline cases, they do agree that discipline cases exist in schools. According to the head teachers very few male teachers are involved with female students. This could be attributed to the fact that the schools are mixed in nature having seen earlier that boy/girl relationship exists. $80 \%$ say that the relationship is not there while $20 \%$ says it exists. Where it exists $80 \%$ say it is solved through counseling while $20 \%$ say that interdiction has been done. 
Table 4:3:6

\begin{tabular}{|c|c|c|}
\hline EXISTENCE OF BOY/GIRL RELATIONSHIP. \\
\hline RESPONSE & FREQUENCY & PERCENTAGE \% \\
\hline YES & 4 & 80 \\
\hline NO & 1 & 20 \\
\hline TOTAL & 5 & 100 \\
\hline \multicolumn{1}{|c|}{ DISCIPLINE CASES 100\% } \\
\hline MALE TEACHERS INVOLVED BY FEMALE STUDENTS. \\
\hline YES & 1 & 20 \\
\hline NO & 4 & 80 \\
\hline TOTAL & 5 & 100 \\
\hline WHAT HAS BEEN DONE TO ON THE ABOVE INVOLVEMENT \\
\hline INTERDICTION & 1 & 20 \\
\hline COUNSELLING & 4 & 100 \\
\hline TOTAL & 5 & 80 \\
\hline
\end{tabular}

Source: Head teachers questionnaires

On the same challenges, which are school based students were asked the following questions.

a. Was it your choice to go to a mixed school?

b. Mixed schools are better than single sex schools.

c. Boys are academically better than girls.

d. Do you feel free in a class, which has boys?

e. Do you have a boyfriend in your school?

f. Are there love relationship between male teachers and school girls?

g. What academic problems do you encounter in your school?

h. What other problems do you encounter in your school?

i. Are there problems of time wastage in your school?

j. $\quad$ Would you like to transfer from your school to a single sex school?

The students responded as follows on whether it was their choices to go to a mixed school. $66.7 \%$ of the students agree while $33.3 \%$ say they are not in mixed school out of choice. Figure 4:3:7

Table 4:3:7 Students Frequency

\begin{tabular}{|c|c|c|}
\hline \multicolumn{2}{|c|}{ CHOOSE TO GO TO MIXED SCHOOLS } \\
\hline RESPONSE & FREQUENCY & PERCENTAGE \% \\
\hline YES & 40 & 66.7 \\
\hline NO & 20 & 33.3 \\
\hline TOTAL & 60 & 100 \\
\hline \multicolumn{2}{|c|}{ WHY CHOOSE MIXED SCHOOLS } \\
\hline SHARE IDEAS & 41 & 68.3 \\
\hline KNOW BOYS/GIRLS & 14 & 23.3 \\
\hline REPRESENT REAL LIFE & 1 & 1.7 \\
\hline IT IS NEAR & 4 & 6.7 \\
\hline TOTAL & 60 & 100 \\
\hline
\end{tabular}

Source: Students questionnaire 
They even give reasons for being in mixed schools. On whether they chose to be in mixed schools the response is as shown in Table 4:3:8. The students $66.7 \%$ say they chose to be in mixed schools meaning they are not there by accident. Their reasons for choosing these schools are:

I) They are able to share ideas with the boys as opposed to when they are only girls.

ii) They learn more about the opposite sex instead of believing in here say.

iii) Mixed schools represent real life because both sexes co-exist just as in real life.

iv) The mixed schools are near home as opposed to boarding school where they go far from parents and other family members.

Table 4:3:8

\begin{tabular}{|c|c|c|}
\hline \multicolumn{2}{|c|}{ MIXED SCHOOLS ARE BETTER THAN SINGLE SEX SCHOOLS } \\
\hline RESPONSE & FREQUENCY & PERCENTAGE \% \\
\hline STRONGLY AGREE & 28 & 46.7 \\
\hline AGREE & 25 & 41.7 \\
\hline STRONGLY DISAGREE & 2 & 3.3 \\
\hline DISAGREE & 5 & 8.3 \\
\hline TOTAL & 60 & 100 \\
\hline BOYS ARE BETTER ACADEMICALLY THAN GIRLS \\
\hline YES & 23 & 38.3 \\
\hline NO & 37 & 100 \\
\hline TOTAL & 60 & 83.3 \\
\hline YES & 50 & 16.7 \\
\hline NO & 10 & 100 \\
\hline TOTAL & 60 & \\
\hline
\end{tabular}

Source: Students questionnaire

A bigger percentage $46.7 \%$ agreed that mixed schools are better than single sex schools. They however deny that boys are academically better than girls with $61.7 \%$ saying no and only $38.3 \%$ say yes. On whether they feel free with boys in school, $83.3 \%$ say yes while $16.7 \%$ say no. The girls however agree that there is boy/girl relationship in school.

Table 4:3:9 Do you have a boyfriend in school?

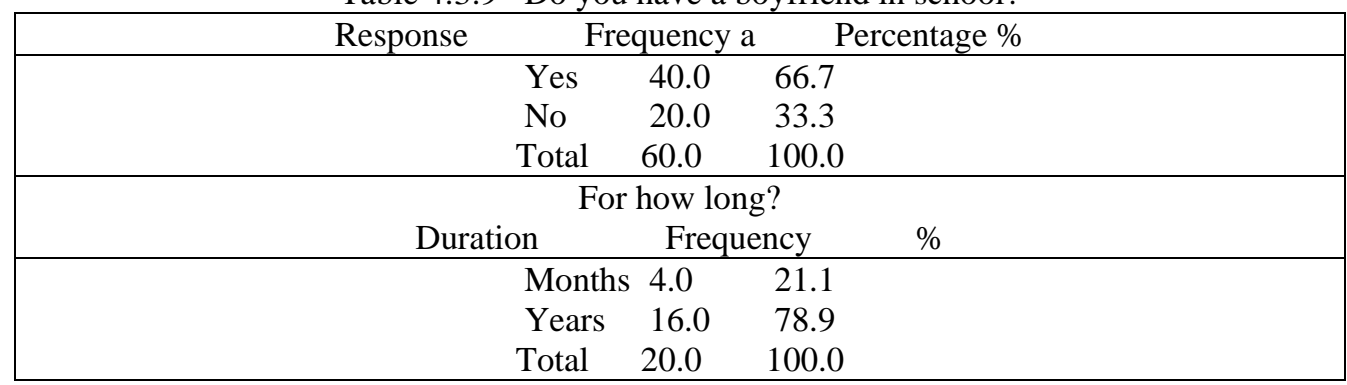

Source: Students questionnaire 
However relationship between male teachers and female students according to the girls is not high as only $41.7 \%$ say they exist, but $58.3 \%$ say they are not there as shown in Table 4:3:10. This can be attributed to the mixed nature of the schools. They see boys every day and even have them as boyfriends. This lowers love relationships between teachers and students.

Table 4:3:10

\begin{tabular}{|c|c|c|}
\hline \multicolumn{2}{|c|}{ LOVE RELATIONSHIP BETWEEN THE TEACHERS \& THE STUDENTS } \\
\hline RESPONSE & FREQUENCY & PERCENTAGE \% \\
\hline YES & 25 & 41.7 \\
\hline NO & 35 & 58.3 \\
\hline TOTAL & 60 & 100 \\
\hline
\end{tabular}

Source: Students questionnaire

When asked about their academic problems they responded as follows.

\section{Problems with teachers}

a) Some teachers favor bright students over the weak ones. They do everything for the bright students instead of motivating the weaker ones thus they lose interest.

ii) Some teachers have a habit of missing most of their lessons. This makes students who can't work on their own to decline even more academically.

iii) Some teachers don't care about the welfare of the students. Students especially girls could be undergoing a stage in life or facing various difficulties making them miss school or not perform as expected. The teachers however do not try to find out what could be wrong.

iv) Some are not approachable and students find it hard to go to them for consultation. Such teachers are not friendly and so students would rather die with their problems than face them.

v) Some don't understand the students. Some teachers don't bother to find out why students are behaving or doing things in a certain way. Instead they draw their own conclusions about the students.

\section{Problems with administration}

i) Suspension. Sometimes the administration suspends students even for minor offences which can be solved through punishments.

ii) Sending students whose parents are not financially stable, home for fees. At times the administration knows that even if you go home you will not get money but you are still sent away.

iii) Very strict. The administration is very strict on things like correct school uniform, time for reporting to school, leaving school without 
permission. They refuse to understand when you try to explain reasons like say why you are not in correct school uniform.

iv) Expulsion. At times you are expelled from school when a matter has been forwarded to the Board of Governors who will most likely listen to the administration.

\section{Problems with Boys}

i) Sexual harassment. Boys do harass girls by touching them and writing to them bad letters.

ii) Disrespectful. They make bad comments regarding girls and therefore hurt their feelings.

iii) They at times answer girls rudely when they ask questions or inquire about anything.

iv) They display an arrogant attitude towards girls.

v) Destructive. Sometimes they are given a book to share and instead of taking good care they cut pictures and write on them.

\section{Problems with fellow girls}

i) Un co-operative. Some feel proud and don't help fellow girls to coop with difficult situation.

ii) Hatred. Some girls hate each other and therefore very unfriendly

iii) Competition. They compete on non-academic issues e.g. beauty.

iv) Jealousy. Most girls don't like to see others with things they don't have thus making them permanent enemies.

Most students do agree that there is a lot of time wastage with $75 \%$ agreeing that they do waste a lot of academic hours and only $21.7 \%$ denying this. They however would not like to transfer from their schools. $85 \%$ say they would not like to transfer as they have already settled, $15 \%$ however do not mind transferring.

\section{Findings}

\section{Summary of the study findings.}

The first objective of this study was how school based factors affect girls academic performance.

The findings are summarized as follows:

a) Admission to form one: When students are being admitted to form one boys are admitted with higher marks than girls. This is usually decided by the Ministry as more often than not even at the KCPE level, the boys still do better in class therefore the girls don't see themselves as capable as boys.

b) Boy/girl relationship: This seems to be a major factor affecting girls in mixed schools. They develop relationship with classmates and get so 
deeply involved as opposed to boys. Even the bright girls who can do well eventually don't make it.

c) The mix nature of the school: This was found to contribute greatly to in discipline although girls are not so much involved in indiscipline.

d) Girls are affected by personal problems with teachers: This comes in the form favoritism of bright students by teachers and missing lessons. With the administration they complain of suspension, being sent home for school fees, being very strict.

The girls further complain of sexual harassment by boys, arrogance and disrespect while fellow girls were un co-operative, have jealousy and a lot of competition.

e) Time wastage: The students especially girls admitted that academic time is used for other things other than learning.

f) Lack of participation class: Girls find it difficult to participate in class especially when they have boyfriends in the same class. This lowers their performance in class work and exams.

The second objective of the study was to determine the possible strategies that can counter the factors, which affect girls' academic performance.

Generally the respondents gave the following as possible strategies.

i) Encourage them to think positively. They should be made aware that they can successful despite the difficulties they could be facing.

ii)Invite resource persons to talk to them especially former girlstudents who excelled academically.

iii) Enlighten them that they have equal ability and opportunity just like boys to excel

v) They should have role models who inspire them. Girls should be made to identify a person they consider a role model and find out how the person excelled. This can be a great inspiration to them

vi)Separation of boys and girls during lessons. So that they don't get intimidated by boys during lessons, girls and boys should be taught separately. This could yield good results.

vii) Giving them leadership roles. Apart from being prefects girls can also be made to lead discussion groups, this will give them confidence.

\section{Discussion}

From the findings of the study it was established that most girls in mixed schools did not perform as well as they were supposed to at KCSE level This is not good as investment in Education satisfies a basic human need for knowledge, provides a means of helping to meet other basic needs and helps sustain and accelerate overall development. Investment in human 
capital through equitable distribution of education opportunity may be used as a fuel to redistribute income and raise incomes of the poor (Psacharopoulos et al 1985). If both boys and girls from such backgrounds successfully exploit educational opportunities and attains quality grades at KCSE, their lives will improve. Girls have to realize this fact as only education can help reduce gender disparity.

The researcher's observation revealed very glaring factors leading to this poor performance of girls. The study found out that the schools do have well trained teachers and head teachers with a lot of experience so this cannot be the reason for girls' poor performance. They have same learning experience with boys and use similar facilities so it was discovered that there are other factors, which make the girls in a mixed school, not do well.

The issue of Form 1 intake is quite grave in the case of a mixed school, as girls looks at it from the point of view of the boys being better off so they get intimidated because we have seen that boys do come with higher marks. This scenario is not seen in single sex schools with just boys or girls. Usually boys do better than girls even at KCPE so the cut off points for girls are lowered. This intake has direct results on performance.

It was also discovered that as much as girls in mixed schools have proper socialization, the issue of boy/girl relationship is so rampant that they put books aside. This concur with the findings highlighted in the Thursday Magazine in the standard; Sept 152005 which says most education stakeholders agree that love relationships between girls and boys in mixed schools are a destabilizing factor. Students especially girls performance deteriorated if they spend a lot of time on the affairs. It is not that girls are not academically capable and this has been said by all the respondents it's their attention that is diverted. The boy does not get involved in the affair at the expense of the books.

Indiscipline is a factor associated with boys in this study but they still do well academically. Girls are involved in indiscipline at a very small \%age so in mixed schools we can't say girls are so in disciplined that they can't do better than boys in any case they talk of boys sometimes giving them a hard time. The indiscipline nature of boys indicates girls so they get scared.

There are cases where girls talk of sexual harassment by boys who touch them and sometimes get away with it. This stops the girls from expressing themselves and even not participating in class so that the boys can view them as less competitors.

There is the issue of bursary and again here there is no preference to girls or boys as both are given equally. They even get an equal amount of kshs. 5,000. Another problem, which was coming out, very clearly is the girls' complaint that teachers favour other students especially the bright ones. In case of mixed schools if the boys are more favoured the girls shy 
off and don't make any efforts in class at all. The boys mock them and make all forms of comments, under such circumstances the girls can't perform well as they feel intimidated. This factor corresponds with a research done by Kitetu (1998) on secondary school classrooms in Kenya. She confirms that teacher's treatment of the different sexes is a major hindrance to academic performance of girls who are treated as 'soft' and boys 'tough'.

There is the mention of relationship between female teachers and girls in schools. If the students feel close to them as the study has shown they will get role models and be motivated. If the female teacher could make it why can't the girl do better?

Ironically despite the many challenges faced by girls in mixed secondary schools the head teachers, teachers and even students prefer mixed schools to single sex schools. They say mixed schools offer socialization and you learn from both sexes therefore you know how to handle them. Very few students would like to transfer from mixed schools. This leaves us with the fact that mixed schools should not really be done away with in any case, pregnancies are not common and teacher/girl relationships are minimal. It is therefore upon the education stakeholders to deal with the issues in the mixed schools which make girls to do poorly in KCSE not doing away with them altogether.

From the above discussions it comes out that some school-based factors that have hindered the girl in a mixed school to perform well in KCSE in Nakuru Municipality. It is the teachers, other education stakeholders who must work very hard for the perception that girls cannot do well in mixed schools is viewed differently. Girls are not weaker academically compared to boys. For education to be beneficial to both genders, the performance at KCSE must be competitive between both boys and girls.

\section{Conclusion}

Through the two objectives of the study, it was established that several school based factors affect girls performance in KCSE in mixed schools i.e. indiscipline, intake marks, relationships and wastage of time .Generally teachers and head teachers cited that several problems that face the girls in mixed schools thus denying them a chance to do well in KCSE. They all gave what they considered a way forward to sort out this problem.

\section{References:}

Abagi, J. O., \& Shale, W. P. (1994). Homosexual based factors affecting participants and performance in schools in Nairobi.

Achola, P. (1987). Social Science Research Methods Hand Book for Africa.

Nairobi: Government Printers. 
Ainley, J., \& Daly, P. (2002). Participation in Science courses in the final year of high school in Australia; In Gender in Policy and Practice. New York : Routlegde Felmer.

Anderson, J. E. (1986). Education Research; an Introduction 4th Edition. New York: Longman.

Asian Development Bank. (2001, September 14). Participatory in Poverty Assesment in Cambodia, Manilla . Retrieved from Asian Development Bank: http://www.adb.org/documents/books/particpatory-poverty/prelims.pdf

Bone, A. (1983). Girls and Girls only schools. Manchester: Equal Opportunities Commission.

Campbell. (1986). Introduction to Educational Administration 3rd Edition. Allyn Bacon.

Dale, R. (1969). A research study in Pupil Teacher Relationships. Vol 1 of mixed or single-sex schooling London.

Dale, R. (1971). Some Social Aspects. Vol 2 of Mixed or Single Sex Schooling?

Dale, R. (1974). Attainment, Attitudes and Overview. Vol 3 of mixed or single sex Schooling?

Dalen. (1996). Methods in Socio Research; . New York: Longman Inc.

Deolalikar, A. (1999). Primary and Secondary Education in Kenya. Nairobi.

Eshiwani, G. S. (1975). Sex Differences in the learning of Mathematics among Kenya High School Students. Nairobi: Bureau of Educational Research .

Eshiwani, G. S. (1983). Who Goes to University in Kenya. Nairobi University: Bureau of Educational Research Kenyatta University.

Eshiwani, G. S. (1985). A Study of Women's access to higher education in Kenya with Special reference to Mathematics and Science Education. Nairobi: World Bank.

FAWE. (1996). The Education Of Girls and Women in Africa. FAWE News Vol 5 No 1.

Gay, L. R. (1981). Educational Research- Competencies for Analysis and Application. Ohio: Bell, Howell.

Goldstein, H. J., Rasbash, M., Yang, G., Woodhouse, H., Nuttal, P. D., \& Thomas, S. (1993). A multilevel analysis of school examination results. Oxford review of Education vol 19, 425-433.

Haanen, D. F., \& Shortfall, S. (1991). The Quality of their education: School Learners views of Educated Objectives and Outcomes. Dublin: ESRI.

Jimenez, E., \& Lockhead, M. E. (1989). Enhancing Girls Learning Through Single Sex Education; Evidence and a policy Corundrum. Educational Evaluation and Policy Analysis Vol .11. No. 2, 117-142.

Kabira, W. M., \& Masingila, M. (1997). ABC of Gender analysis. Nairobi: FAWE. 
Kabira, W. M., \& Murther, W. (1994). The road of empowerment; Nairobi African Women Development Network . Nairobi: FEMNET.

Karugu, F. A. (1987). An examination of Socio-cultural factors hindering higher education and status achievement. . Nairobi: Basic Resource Center. Kathuri, N. J., \& Pals, A. D. (1993). Introduction to Educational Research. Nakuru: Egerton University.

Kerlinger, F. N. (1973). Foundations of Behavioural Research. New York: Holt- Rinerhart and Winston Inc.

Kihumba, W. (1997). Education and Culture amomg the Lesotho; a workshop presentation.

Kinyanjui, K. (1982). Education and Inequality in Kenya Seminar Paper No 2037. Research Expereience as Issues .

Koul. (1984). Methodology of Education Research . New Delhi : Vikas Publishing House , P.V.T Ltd.

Lehrer, S. (2000). For Girls Only; Making a Case for Single Sex Schooling. Contemporary Sociology Vol 29 No 6, 823.

Lloyd, C. B., Mete, C., \& Sathar, Z. A. (2007, September 14). The effect of Gender Differences in Primary School Acces, Type and Quality on The Decision to Enroll In Rural Pakistan. Retrieved from Population Council: http;//www.popcouncil.org/pdf/wp/164pdf

Maleche, A. (1976). A new status for women in Kenya. East African Journal.

Mampele, A. J. (1994). Equity Policy; A framework of questions, Equity, Reality Issues and their Implications. Capetown: UTC Press.

Maundu. (1996). Evaluating Education and Community Development Programmes. Nairobi: University of Nairobi Press.

Mugenda, O., \& Mugenda. (1999). Research Methods, Qualitative and Qualitative Approaches. Nairobi: Nairobi Acts Press.

Nkapa, N. (1997). Educational Research for Modern Scholar. Enugu: Forth Dimension Publishing .

Obura, A. (1988). he image of girls and women in primary school text books in Kenya

Okonkwo, C. E. (1987). Mixed or single sex schools Education and Development. Journal of the Nigerian Education Research Council Vol 3 No.2.

Ormerud, M. B. (1975). Subject preference and choice in coeducational and single sex secondary schools. British Journal of Educational Psychology Vol 45, 257-267.

Orodho, A. J. (2003). Essential of Educational and Social Science. Masola Publishers.

Orodho, A. J. (2004). Elements of Education and Social Science Research Methods . Masola Publishers. 
Orodho, A. J. (2004). Techniques Of Writing Research Proposals and Reports in Education And Social Sciences. Masola Publishers.

Pale, \& Krystal. (1975). Impact of Gender and Socio Economic Factors on Learning Achievements in Schools.

Pewitt. (1980). An Introduction to Field Research . London: Allen and Uwin. Psacharopoulos , G. (2004). Returns to Investment In Education; A further update: World Bank Policy Research Working Paper. Washington D.C: World Bank.

Psacharopoulos. (1985). The Ecocmics of Higher Education in Developing Countries; Comparative Education,.

Robinson, W. P., \& Cullibrad, E. (2004). Single Sex Teaching And Achievement in Science Research Report. International Journal of Science Education Vol 26 No 6, 659-675.

SACMEQ. (2005). A study of the condition of Schooling quality of Education. Nairobi.

Sathar, Z. A., \& Lloyd, C. B. (2000). Investments in Children's Education and Family Building Behaviour in Pakistan. Findings for Rural NWFP and Punjab.

Schmeider, F., Coutts, L., \& Starr, M. L. (1988). In favour of coeducational attitudes of students from coeducational and single-sex high schools. Canadian Journal of Education Vol 13, 479-496.

Smithers, A., \& Robinson, P. (2006). The Paradox of Single Sex and Coeducational Schooling. Buckingham: Carmicheal Piers.

Smock, A. (1977). Women and Education and role in Kenya. Institute of Development Studies working Paper No 316.

Spender, D., \& Sarch, E. (1980). Learning to Lose; Sexism and Education,. London: The women's press.

Stabiner, K. (2002). All Girls : Single- Sex Education and Why it Matters. New York: Riverhead Books.

UNESCO. (1970). Education and Advancement of Women pairs. UNESCO.

UNESCO. (1996). Indicators on Girls and women Education: Nairobi. Nairobi: UNESCO.

UNESCO. (2003). Gender and Education for all The leap of equality . Paris: UNESCO.

UNESCO. (2004). Gender- based issues and trends in ICT Applications in Education in Asia and the Pacific. Bangkok..

UNICEF. (2003). Life Skills Education with a focus on HIV/AIDS- Eastern \& Southern Africa region. Nairobi: UNICEF.

Wakhungu, J. (2004, December 16). science rooms, Chilly for girls. The Standard Newspaper. 